\title{
Civil Service and Public Employment
}

\author{
Christoph Reichard and Eckhard Schröter
}

\section{INTRODUCTION}

The term 'civil service' denotes more than the body of personnel in the employ of government. It also refers to a set of rules and institutional arrangements embedded in political and administrative traditions and cultures. It is this wider concept of the German civil service and public employment system that we refer to in this chapter. Our chapter addresses the total public sector workforce regardless of the level of government (federal, state or local) or employment status (governed by public or private law). In doing so, we are in part being untrue to the German usage of the term 'civil service' (Beamtentum), which is reserved for holders of a 'civil servant' status (Beamte) governed by public law (see below for further details). Rather, in the following we refer to paid public sector personnel generally, including civil servants and public employees at the federal, state and local levels. To be sure, the body of public personnel is

\footnotetext{
C. Reichard $(\bowtie)$

University of Potsdam, Potsdam, Germany

e-mail: Reichard@uni-potsdam.de

E. Schröter

German Police University, Münster, Germany

e-mail: Eckhard.Schroeter@dhpol.de
}

(C) The Author(s) 2021

S. Kuhlmann et al. (eds.), Public Administration in Germany, Governance and Public Management, https://doi.org/10.1007/978-3-030-53697-8_13 
no monolith. It brings together a diverse group of professions and occupations in a variety of sectoral policies and administrative tasks. For the sake of clarity and consistency, we confine ourselves in what follows, unless otherwise stated, to the administrative core of the civil service, which is trusted with non-technical tasks in the executive apparatus of government.

\section{Civil Service Systems Compared: What Kind of an Animal Is the German Civil Service?}

When looking at foreign civil service systems from the outside, we tend to search for commonalities and differences that we can relate to systems that are more familiar (van der Meer et al. 2015). For a more systematic review, a number of dimensions suggest themselves against which national civil service systems can be compared. A first and simple question to answer is to what extent the civil service has evolved as a distinct set of employment regulations and as a body of personnel separate from the private labour market. In this respect, the prevailing notion of statehood plays a decisive role. State traditions that place a higher emphasis on the role of 'the state' vis-à-vis society and the economy, and in which public administration is trusted with a more comprehensive set of responsibilities to contribute to the development of society at large (often typified by the French or German variants of the continental European tradition)-as opposed to the Anglo-Saxon state tradition with a more instrumental role of the state (as function of the political, societal and economic forces)- tend to produce civil service systems, which carry a greater social prestige, are more distinct from private sector employment, and form a greater identity as 'servants of the state'. This argument is underpinned by legal and religious traditions in Europe, in which the Roman Catholic tradition of codified law is pitted against the case-based common law tradition. Finally, the sequence of historical developments seems to make an important difference in this respect. As a rule, the bureaucratisation and professionalisation of the civil service (and public administration as a whole) in German states preceded the advent of mass democracy. As a consequence, judicial control of the legality of administrative acts had been well in place long before (party-)political control of the executive apparatus was established. Pulling these threads together, we can conclude from this section that the German civil service-based on a strong public law and Rechtsstaat tradition-differs from many Anglo-Saxon public employment systems in that 
it is a well-established body of personnel systematically governed distinct from private-sector employment.

The question of open and closed civil service systems is another litmus test for international comparison. When compared to public employment in the US (at one end of the spectrum), the German approach is classified as particularly closed. One of the underlying reasons for this classification lies in the dominant career-based system of the German civil service, which differs systematically from job-based or position-based approaches in other systems (primarily those of Anglo-Saxon or Scandinavian provenience). It follows from the career system that entry into the civil service typically takes place in an early part of the work biography-with an expectation that the individual completes his or her work life in the employ of government. For this reason, a high level of job security is coupled with disincentives to leave government service early. In addition, loyalty to the public employer is rewarded, for example, by extra pension benefits and, of course, opportunities to move up the career ladder. In line with this thinking, seniority is a significant factor for promotion and remuneration. In return for government's loyalty, public employers impose specific duties on their employees (particularly on 'civil servants' as a distinguished status group), which requires them to show political moderation while in office and may even restrict-in the case of civil servants-their civil liberties (e.g. the right to go on strike). What is more, government employment and access to specific grades in the career ladder is, as a rule, dependent on certain levels of qualification and types of exams - qualifications and exams that are often (and sometimes exclusively) offered by government-run training institutions. Compare this system to the position-based system, the significant number of lateral entrants and rather frequent intersectoral changes, for example, in the US civil service (in-and-outers), and the relatively closed nature of the German civil service system is easily discernible. In relation to its French neighbour, however, the German system of public employment shows strong elements of openness. The key reason for this change in perspective can be found in the decentralised structure of Germany's politico-administrative system, which by definition provides more access points to public sector employment. Even at the same level of government, individual public organisations tend to pursue-though governed by the same set of regulations - their own recruitment, selection and hiring processes independent of one another. Due to the lack of a central personnel or civil service agency, public personnel policies tend to be-within the boundaries of the law-more decentralised and pluralist 
than in France. This trend is further reinforced by the relative plurality of institutions of higher learning that provide talent pools for admission to the higher civil service.

\section{How Does the German Civil Service Measure Up? Size and Structure of Public Employment}

The size and structure of public employment not only mirrors the relevance and resources of the public sector in any given nation; it is also indicative of the relative power of levels of government, the significance of particular government functions as well as current and future challenges for human resource management in government organisations. Regarding our earlier discussion on statistical problems, the data presented below cover general government employment only and exclude, for example, employees of state-owned enterprises and other legally independent entities or organisations that provide public goods or services on a for-profit or notfor-profit basis.

Compared to other industrialised countries, the size of the German public sector in terms of employment is relatively moderate. General government employment relative to total employment amounts to no more than 12 per cent, which ranges significantly below the Organisation of Economic Co-operation and Development (OECD) average of 18.1 per cent. In fact, only a few nations fall below this level (notably Japan and South Korea), while Anglo-Saxon countries show employment levels closer to the OECD average and Nordic countries top the list with levels hovering around the 30 per cent mark (OECD 2019, 85). However, one should be quick to make mention of the fact that the vast majority of social services in Germany tend to be provided by welfare associations that operate-by definition-outside the public sector for statistical purposes. Interestingly, the relative size of the public sector-after years of contraction-has now reached the levels of the late 1960s and early 1970s, which ushered in a phase of massive increases in public employment (in Germany and much of the OECD world). In Germany, this development reached its peak shortly after German unification, when about 15 per cent of all employees were on the government's payroll (1991). In absolute numbers, there were at that time some 6.7 million people in the employ of the public sector-a number that is now down to 4.8 million employees. Given the much higher levels of public employment in what used to be the German Democratic Republic, the integration of the public workforce in 
the eastern German states resulted in a significant increase in public personnel numbers. However, public employment cut backs (in the whole of the country) began as early as the mid-1990s and were primarily driven by fiscal concerns, but also by reform measures such as contracting-out, privatisation and corporatisation.

For a more differentiated picture, Table 13.1 shows the distribution of the total public workforce across levels of government and between the two major employment categories (civil servants and public employees; see below for more details).

As for levels of government, the figures in Table 13.1 reflect the division of labour in Germany's variant of federalism, which shifts administrative responsibilities per se to the states or Länder as well as to local government as major service providers. It flows from this that more than half of total government staff is employed by the Länder where the bulk of executive and personnel-intensive tasks are carried out. In particular, Länder governments employ teachers, police officers and members of law enforcement agencies and the judiciary. In comparison, the size of federal government in terms of employment figures is conspicuously small with less than eight per cent of the total (when military personnel are included, this percentage goes up slightly to roughly ten per cent). ${ }^{1}$

As for employment categories, civil servants only account for a little more than one-third (38.4 per cent) of the entire public workforce in Germany, while nearly two-thirds qualify as 'public employees' (for the specifics of these status differences see below). However, the relative (numerical) strength of these status groups varies significantly across levels

Table 13.1 Public employment (excluding soldiers) in full-time employment (FTE) by government level and employment category (as of 30 June 2017; rounding differences possible)

\begin{tabular}{llllr}
\hline Government level & $\begin{array}{l}\text { Civil } \\
\text { servants }\end{array}$ & $\begin{array}{l}\text { Public } \\
\text { employees }\end{array}$ & TotalFTEs & $\begin{array}{c}\text { Total } \\
\%\end{array}$ \\
\hline Federal government & 173,200 & 135,500 & 308,700 & 7.7 \\
Länder government & $1,169,900$ & 935,100 & $2,105,000$ & 52.4 \\
Local government & 172,000 & $1,099,300$ & $1,271,300$ & 31.7 \\
$\begin{array}{l}\text { Social insurance administration (incl. } \\
\text { employment offices) }\end{array}$ & 26,800 & 301,700 & 328,500 & 8.2 \\
Total & $1,541,900$ & $2,471,600$ & $4,013,500$ & 100.0 \\
\hline
\end{tabular}

Source: Destatis $(2018,86)$ 
of government. While the federal and Länder levels employ more civil servants than public employees (56.1 per cent and 55.6 per cent respectively), the opposite holds true at the local level, where civil servants are a small minority representing only 13.5 per cent of the total local workforce.

In Table 13.2, we continue our analysis by breaking down personnel numbers according to their position in the administrative hierarchy. In doing so, we employ a well-established, but very broadly defined measure and refer to the legal classification of 'career classes' in the German civil service as well as their equivalents with regard to the grading of the jobs of public employees. As shown below, Germany's public sector workforce is structured into different career classes, following the traditional civil service system.

As the data reveal, the vast majority of civil servants are employed in the 'middle management' and 'senior management' categories, while the lion's share of public employees is grouped under the lower category of 'clerical services'. It should be noted that career structures have considerably changed over time, particularly with regard to civil servants. Over the past thirty years, for example, the proportion of civil servants qualifying for senior management has more than doubled.

In addition to the data provided in Tables 13.1 and 13.2, we can distil from available statistics a number of important developments and potential challenges to which we will return in our concluding section. To begin with, the German public sector is no exception from the more general trend in many OECD countries that shows, in quantitative terms, an increasing 'feminisation' of public employment. In fact, no less than 57 per cent of public sector staff are women (DBB 2019). However, this

Table 13.2 Public employment (headcount) by career classes or equivalent grades for public employees, excluding soldiers and staff in training (as of 30 June 2017)

\begin{tabular}{llclc}
\hline Career class/grade & \multicolumn{2}{c}{ Civil servants } & \multicolumn{3}{c}{ Public employees } \\
\cline { 2 - 5 } & Number & $\%$ & Number & $\%$ \\
\hline Senior management & 596,500 & 38.1 & 378,400 & 14.1 \\
Middle management & 783,500 & 50.1 & 838,900 & 31.3 \\
Clerical services & 182,700 & 11.7 & $1,463,700$ & 54.6 \\
Total & $1,562,700$ & 100 & $2,681,000$ & 100.0 \\
\hline
\end{tabular}

Source: Authors' own compilation based on Destatis $(2018,29,57,82)$ 
percentage also raises serious questions about gender-specific employment patterns since women are more likely to work in the 'public employees' category or in specific sectors of government employment (such as social services, healthcare or teaching) and tend to occupy positions in lower and middle management.

A related feature to female employment is the increase in part-time work in the German public sector. In fact, German public employers seem to offer attractive opportunities to work part-time as roughly one-third of the total workforce (32 per cent, the majority of whom are women) has made part-time arrangements. Again, this trend provides more of a mixed bag. On the one hand, part-time arrangements signal a greater openness and flexibility on the part of public employers to make the workplace more inclusive through rearranging work schedules to establish a better worklife balance or new work models. On the other hand, this trend may also reflect the government's austerity measures and still shows a significant imbalance between men and women working part-time.

Finally, the data reveal the urgency of demographic challenges in the public sector. While Germany's society as a whole is ageing, Germany's public sector workforce is even more so: in 2017, no less than 27 per cent of the total staff employed by government authorities were aged fifty-five and over. This tidal wave of retirees raises complex questions about future talent pools, the attractiveness of the public sector as an employer and the management of an increasingly diverse government workforce.

\section{How Does the German Civil Service Work? Major Characteristics and Features}

\subsection{The Weberian Bureaucrat as a 'Leitmotif': 'Civil Servant' and 'Public Employee' as Competing but Also Converging Status Models}

Given its historical and cultural legacy, the process of bureaucratisation of the modern (European) nation state is the foundation on which the German professional civil service still rests. ${ }^{2}$ The reference to bureaucratisation suggests that core elements of that newly institutionalised civil service aspire to the ideal-typical characteristics of the Weberian bureaucratic staff organisation. In line with Weber's ideas, the appointment of a civil servant is a unilateral administrative act-as opposed to a bilateral 
contractual agreement. It also flows from this that employment conditions (including compensation and benefits) are exclusively governed by public law. This model of a government bureaucrat has served as a leitmotif for public employment in Germany to this day-despite the variations and changes to which we will turn below.

The institution of the 'public employee'-introduced in 1920, marking the advent of an expanding public sector with extended welfare servicesdeviates from the traditional role model. Designed as a private-law employment status, the labor conditions of public employees are the result of collective bargaining between government and labour representatives. In keeping with this principle, the social insurance regulations (i.e. health benefits and pension plans) for private-sector employment will generally apply - and so do the rules for industrial action, which, of course, safeguard the right to go on strike.

However, it is also fair to say that the status of 'public employee' emulates the traditional role model of a 'civil servant'-notwithstanding its roots in private labour law. Most importantly, public employees also enjoy high levels of job security and-under certain conditions-even job tenure equivalent to that of a civil servant. Also, compensation schemes have significantly converged, extra benefits have been added and, in practice, a career system is also in place for public employees (who are, in principle, hired for a specific job)—provided they bring equivalent levels of formal education and job experience. While differences in the nature of these employment categories still exist, the role model of public employment - to all intents and purposes - is more unified than the duality of the German employment system suggests.

In administrative practice, the growing similarity between the status groups is also reflected in the relatively indiscriminate use of the different personnel categories when it comes to filling public sector positions. Constitutional law stipulates that 'the exercise of sovereign authority on a regular basis' shall be reserved for civil servants (Article 33 (4) of the Basic Law), which in particular applies, for example, to police officers, tax inspectors, law enforcement officers, court administrators and members of the prison service. In general government employment, however, the practice of assigning certain functions to civil servants or public employees varies significantly across the nation. Rather than applying a systematic yardstick for making these decisions, the allocation of civil servants or public employees to specific public sector posts primarily reflects historical 
path-dependencies or political policy preferences at the relevant government level.

Still, the formal bifurcation of the employment categories in public sector employment remains a constant bone of contention. For one, each employment status creates its own group of people (constituency)—which provides a base for organised interests - who fight to protect their privileges or to even out any remaining differences. On top of that, there also appears to be a more fundamental, if not ideological, debate as to what status proves to be more efficient and/or legitimate. The real divide, however, is rather the distinction between employment inside and outside the public sector.

\subsection{Steering and Coordination in the German Civil Service: Legal Frames, Collective Bargaining and Civil Service Politics}

As for the steering and coordination of public sector employment, there are two major coordination and guidance mechanisms in public sector employment primarily at work: legal frames and collective bargaining agreements. One should be quick to add that both mechanisms are deeply entrenched in political and professional cultures. In addition, organised interests in the form of public sector unions play a significant role in the governance of the German civil service.

The remarkable stability and continuity of the German civil service is owed largely to the constitutionally enshrined 'fundamental principles', which govern the status of civil servants nationwide. This set of rules, upheld and interpreted by authoritative rulings of the Federal Constitutional Court, provides a powerful legal frame for any civil service policy in the country. In a similar vein, federal government serves as a rule-maker, not only for its own jurisdiction of federal civil servants, but also for civil servants of state or Länder government. However, this role has been drastically curtailed in the wake of the devolution of federal government prerogatives to the Länder as part of a constitutional reform package (the so-called Reform of Federalism I of 2006). As a result, the detailed rules governing the recruitment, employment conditions, benefits, pay scales and pension schemes of civil servants in the Länder have been decentralised, while a broader nationwide frame of basic principles is still in place, allowing, among other things, for the transfer of civil servants across states as well as between federal and state governments, and vice versa. 
The system, however, is not only vertically decentralised but also horizontally fragmented. From an organisational point of view, Germany does not utilise a nationwide civil service commission or agency, which tends to centralise recruitment, selection or hiring processes with uniform standards. At the level of federal and state governments, the competencies for personnel affairs are widely dispersed with individual government departments being in charge of their own hiring decisions. The relevant ministries of the interior have primarily procedural competencies and coordinative functions, and oversee civil service training institutions in their jurisdictions. At the local government level, personnel functions tend to be more concentrated in single human resource management (HRM) departments, although various operative functions have been decentralised to line departments in the wake of the New Public Management (NPM) reforms of the 1990s (e.g. Demmke and Moilanen $2010,143)$.

In addition to legal frames, collective bargaining-designed for determining the rules of engagement for public employees-provides another major instrument of coordination and steering. Remarkable by any international standard, the level of collective bargaining is rather centralised and comprehensive. Negotiations are organised in a corporatist setting of interest mediation with peak organisations of public sector unions facing representatives of public sector employers. These talks are held in different rounds: one bargaining agreement covers all Länder governments and their employees, whereas another round of negotiations covers federal government as well as local government employees.

While public employees rely on the bargaining powers of strongly organised public sector unions (vested with the power of taking industrial action), civil servants are stripped of the right to go on strike and are dependent on legislative acts taken by federal parliament or state assemblies to determine their working conditions. What appears at first sight to be a disadvantageous situation for the 'servants of the state' may not be such a bad deal after all. To begin with, political conventions seem to soften the blow rather comfortably because federal and state governments and legislatures tend to follow suit (albeit with some delay or minor changes) once an agreement has been reached for public employees. What is more, civil servants as a collective status group tend to find many advocates sympathetic to their cause in German legislatures. After all, roughly one-third of the members of the national parliament (Bundestag) and almost half of the delegates of state assemblies hold a civil service status. 
In addition, the interests of civil servants and public employees alike are represented at the organisational level by so-called personnel councils, which are an integral part of Germany's system of co-determination that applies to both the private and public sectors of employment. As a result, each administrative entity has such a personnel council as part of its own governance structure. This council has specific rights and responsibilities whenever employees' interests are at stake-a wide jurisdiction, which gives representatives of public personnel at the organisational level farreaching co-decision rights in matters of organisational changes, recruitment and promotion decisions or the allocation of performance-based payments to the workforce.

\subsection{Recruitment and Qualification}

Given its strong emphasis on professionalism and formal qualifications as entry requirements, education and training play a central role in civil service regulations and policies. The German public sector is a large and multifaceted employer and major provider of numerous education and training programmes. Although government institutions recruit various categories of already well-educated and trained staff, for example in areas such as engineering, healthcare and teaching, the government is also very active in providing its own separate training programmes in a wide range of occupational fields for about 200,000 trainees. Apart from general administration, these specialised training programmes are offered, for example, to future police officers, tax inspectors, court administrators, social insurance officials and social workers.

Germany belongs to a group of countries that require comprehensive pre-service education and training as an essential qualification for future members of the public sector workforce. Accordingly, applicants for a civil service position usually have at first to pass an intensive educational programme, either in the form of an apprenticeship or as a study programme at a public or government-specific university (Reichard and Schröter 2018).

Access points to the administrative career ladder are, in principle, organised according to distinct levels of education. In the 'clerical class' category, skilled (manual and non-manual) workers and service personnel who have successfully completed a two- or three-year apprenticeship on the job coupled with training in a vocational school (dual system) provide basic administrative or technical services. One level up, entry into the middle management range of the civil service, often referred to as the 
'backbone of the civil service', requires a three-year bachelor's degree. As a rule, this degree has to be completed at a university of applied sciences, which caters specifically to prospective civil servants and offers courses of study approved by the relevant interior ministry as an entry qualification. Senior management levels of government employment are filled by university graduates (bringing with them a master's degree or equivalent) recruited from the university system at large-most frequently from programmes in law, but also from the social and political sciences, public management and administration, and economics. In addition, successful candidates have to complete a two-year traineeship programme (or 'preparatory service') before they qualify for tenure as a civil servant.

\subsection{Compensation Schemes and Benefits}

Salaries of civil servants depend on the assigned post or rank (i.e. the pay grade in the respective career class). ${ }^{3}$ Compensation for the majority of civil servants is based on pay scale A, covering fifteen grades from A2 (simple manual tasks) to Al6 (section head of a ministry). For more senior grades, there is a specific pay scale B with eleven grades. While the latter scale is not subdivided, each grade of scale A is split up into eight different steps. A civil servant gradually passes the different steps of a grade before he or she may be promoted to the next grade. Advancement to the next step is based on individual performance and seniority. Additionally, civil servants receive various kinds of allowances, for example family allowance. For the past twenty years, civil servants have had the opportunity to receive additional one-off bonus payments for outstanding performance. At the federal level, the number of performance-based bonuses are, however, generally limited to 15 per cent of that status group in an organisation. Also, these payments are not supposed to exceed seven per cent of the basic salary level.

The compensation of public employees is based on the collective agreements drawn up between the public employers and the trade unions and is determined by the actual task requirements. Actually, the pay scale for public employees largely follows the pay scale A for civil servants: it consists of fifteen grades (groups) and each grade is subdivided into six steps. Although, in theory, public employees are assigned to certain positions, in practice they enjoy similar promotion opportunities as civil servants. In addition to other kinds of allowances, public employees may also receive performance-based pay, although with currently usually only one per cent of salaries in a rather marginal form (Kuhlmann and Wollmann 
2019). The practice of performance-based pay for public employees is quite diverse in the various government institutions (for more details see Chap. 21).

Civil servants in Germany are entitled to comparatively high pension levels. In fact, the replacement rate can be as high as 71.75 per cent, depending on the number of years served. These pension payments are largely financed out of the general budget (as opposed to special pension provisions or any kind of insurance system). Civil servants do not make any significant contributions themselves to their pension plans during their active period of service. ${ }^{4}$ Understandably, the current pension system for civil servants is causing growing fiscal concerns, particularly in view of the 'tidal wave' of prospective retirees in the years to come. How to cope with this huge fiscal challenge is part of a controversial and soul-searching debate in German politics. Public employees, in contrast, receive their retirement payments from the national statutory pension insurance system. Additionally, they receive payments from a supplementary occupational pension scheme as agreed between government representatives and the unions. Like any other private sector employee, public employees make mandatory monthly contributions to public insurance funds (covering the risks of unemployment, sickness, long-term care as well as old age). According to the principle of parity, contributions to public insurance funds in Germany are equally divided between employers and employees.

Civil servants also enjoy privileges with regard to their healthcare. In contrast to public employees, they opt out of the statutory public health insurance system and subscribe to a private health plan. In addition, they are entitled to government allowances to cover health-related expenses. As a rule, about half of these costs are covered by the government allowance, while the other half is taken care of by the insurance plan.

In the past-and particularly with regard to certain professions like engineering, computer science or information technology and management-compensation in the German public sector was often perceived as being uncompetitive compared to the private sector. More recently, public sector pay, at least in some professions and career classes, appears to have become more attractive. Although the 'service to the public' may indeed be seen as advantageous by many applicants (compared to for-profit employers), and while the afore-mentioned social benefits and relative job security may also count for 'going public', the increasing competition for 
young talent in a period of demographic change will still most probably be a major challenge for public employers.

\subsection{The German Civil Service at the Interface Between Politics and Administration}

Despite its legitimate claim to Weberian and bureaucratic heritage, the German civil service is at the same time an institution that operates in a highly politicised environment of an open society and a liberal mass democracy (see also Chap. 10). In fact, a lot of civil service rules and practices are-beyond the image of the law-clad nature of regulations-the result of political bargaining and negotiations. In addition, many civil servants and public employees take an active role in interest mediation and party politics.

The German administrative system does not treat civil servants (let alone public employees) - in stark contrast, for example, to the British case-as political eunuchs. Irrespective of their rank, they are free to be openly affiliated with political parties and stand for elections at any level of government without jeopardising their civil service privileges. (Once elected to legislative office, for example, they are entitled to take leave of absence, a period of time that will, nonetheless, count towards the promotion clock.) Indeed, a significant percentage of civil servants, particularly in the higher ranks of the administrative hierarchy, carry party books ${ }^{5}-\mathrm{a}$ fact that prompted a British observer to nickname the then West German civil service a 'party-book administration' (Dyson 1977). While discussions about party-political patronage of civil service posts flare up recurrently at the margins of the political discourse, it is widely recognised that this political affiliation signifies a healthy relationship between political parties and civil service members in a liberal democracy (for this discussion see also Schröter 2004).

\section{How the German Civil Service Has Changed or Is Supposed to Change: Major Challenges AND REFORM TRENDS}

The German civil service system has shown a remarkable degree of stability and continuity over a long period of time. In a country known for its drastic regime changes during the past century-all of which have had severe repercussions for European and world politics too- the established 
orthodoxy of a civil service model based on the tenets of a Weberian professional staff organisation stands out for its hyperstability. Rather than documenting and analysing processes of administrative change, it appears even more rewarding to discuss and explain the degree of continuity.

A major source of stability are the constitutionally enshrined traditional principles of the civil service. As a consequence, the bar for 'gamechanging' innovative projects has been raised too high for most reform coalitions. Moreover, the decentralised and fragmented nature of the administrative system does not allow for one single, resourceful political actor. What is more, the current institutional arrangements serve the organised interests of their constituencies. Seen from this angle, it is not the persistent legal frames, but the balance of political power and interest representation that keep the current set of regulations in place. What also stabilises the existing system is the fact that public sector employment still carries an element of social prestige and the established principles of the civil service are generally respected by the public (rather than challenged by high levels of public disgruntlement and discontent). It is indicative that the most ambitious reform of civil service law during the early 1970s - following a political sea change from a right-of-centre to a left-ofcentre government led by Social Democrats-was eventually aborted. While the reform proposals aiming at a unified employee status and less opaque approaches to personnel management still provide a rich source for intellectual stimulation and academic analysis, they have failed miserably in politics.

This is not to say, however, that change has never come to the established system of public sector employment. Rather, most developments in the civil service have been immanent to this existing paradigm of public bureaucracies. In other words, we have seen changes leading to 'more or less of the same', that is the bureaucratic fine-tuning of regulation and internal human resource management, the shift of competences between levels of governments, or the cutback or expansion of civil service posts, and the adjustments of pay scales and fringe benefits according to fiscal requirements. What we have not seen, however, is a massive approach of 'de-privileging' the civil service (Hood 1995) as has been the case in many Anglo-Saxon countries. To the contrary, the most significant reform activity involving the German civil service (i.e. the process of administrative transformation in the wake of German unification) was driven by the desire to restore the traditional notion of the civil service. By way of contrast, reform elements borrowed from private management or market/ 
efficiency-driven movements (such as the reform wave of the new public management) have made inroads only to a moderate degree.

A number of individual reform programmes merit specific mention because their consequences have significantly shaped current civil service practices. First, most fundamentally, the reform of education and training (at first pertaining only to civil servants, it also set standards for public employees) during the 1970s introduced a broader element of academisation to the level of middle management in the civil service. Today's 'universities of applied sciences' date back to this reform measure, which also laid the foundation for later reform towards bachelor degree programmes for mid-level civil servants. Second, the massive quantitative changes to the public sector workforce since the mid-1990s cannot be underestimated. They also stand out when compared to other countries. Drastic cutback measures hardly qualify as 'reform' in a pro-active and qualitative sense. However, the downsizing of the total number of public administrators has been remarkable and has left its mark on the overall resources and structure of public employment. A third strand of reform, intimately linked to the size of the public sector, refers to the out-migration of public personnel to hived-off corporations. In fact, most of the managerial reform package has touched the civil service indirectly by way of formal privatisation (particularly at the federal level with regard to the national railroads or postal and telecommunications services, and a significant share of utility companies and service providers at the local government level). As a result, the rules governing the administrators who remained in public employment have largely stayed intact.

It is a matter of public debate whether this record of accomplishment sufficiently prepares the civil service as an institution to deal adequately with current and future challenges. As for demographic changes, the civil service will have to prove its attractiveness as an employer to new cohorts of talent. Not only are these talent pools drying up-just when they are needed most - but it is also quite likely that a young generation of potential applicants will bring new expectations of their desired work environment-an environment that may clash with the traditional practices of the civil service. Demographic (and cultural) changes, however, also question the extent to which the civil service mirrors the community it is supposed to serve. It flows from this that questions of inclusiveness and equitable representation of groups - in line with the aim of gender parity-are more likely to play a more prominent role in the future. 


\section{Lessons Learned and Concluding Thoughts}

Moulded in traditional forms of Weberian bureaucratic staff organisations, the German civil service represents a classical continental European administrative system. It stands out from this category of employment systems, however, because it is relatively small in size and highly decentralised in terms of its structural layout. Its guiding principles have remained largely intact-despite the series of radical regime changes in German historyover the course of more than a century. In particular, the established public employment system has proven relatively impervious to external pressure from market/efficiency-driven reform measures in the wake of the new public management movement.

This legalist, merit-based career system of government employment comes with a series of advantages. Civil service members tend to be well trained for the functions they have to perform. In addition, training programmes and qualifications are also tailored to the specific needs of the public sector. Given the high level of strongly entrenched professional standards (underpinned by legal controls), the civil service system is geared to produce procedural fairness and low levels of corruption or cronyism and nepotism. However, the civil service also suffers from rigidity and inefficiencies that tend to stifle motivation and breed frustration among civil service members and clients of public services alike. In addition, its barriers to entry and exit work against intersectoral mobility and limit the access of public employers to sources of future knowledge and innovative ideas.

Despite its bureaucratic heritage, the German civil service shows a remarkable measure of decentralisation and adaptability. It appears to be flexible enough to accommodate different choices by sub-national governments or functional requirements by specific government agencies or local authorities. It has also proven adaptable to social and political changes. What is more, the institutional setting of the civil service as a whole is well embedded in the political environment and its system of organised interest representation. With this in mind, we seem to be on relatively safe ground in suggesting that the existing balance of political and organisational interests will keep the established employment system on a relatively stable path for future developments. 


\section{Notes}

1. In 2017, the Federal Armed Forces accounted for 165,200 FTEs, which brings the total public employment (including soldiers) to 4,179,200 FTEs.

2. In fact, this legacy dates back to 1794 in Prussia or 1804 in Bavaria, when those (and other) German states formed modern executive branches of government.

3 . The following description focuses on the federal level; for more details see Federal Ministry of the Interior $(2014,82-101)$.

4. As a (mostly symbolic) nod to making contributions, a 1999 federal law stipulates that civil servants' pay rises should be 0.2 percentage points below the pay rise for public employees. The savings are used to build up a pension fund to augment future pension payments from the annual budget (starting 2032).

5. Between 1981 and 2005 , the percentage of party members among the top three ranks in ministerial departments has ranged consistently between 50 and 60 per cent.

\section{REFERENCES}

DBB. (2019). Zahlen, Daten, Fakten 2019. Retrieved August 14, 2019, from https://www.dbb.de/fileadmin/pdfs/2019/zdf_2019.pdf

Demmke, C., \& Moilanen, T. (2010). Civil Services in the EU of 27. Frankfurt: Lang.

Destatis. (2018). Finanzen und Steuern. Personal des öffentlichen Dienstes. Fachserie 14 Reihe 6. Wiesbaden: Statistisches Bundesamt.

Dyson, K. (1977). Party, State, and Bureaucracy in Western Germany. Beverly Hills, CA: Sage.

Federal Ministry of the Interior. (2014). The Federal Public Service. An Attractive and Modern Employer. Berlin: BMI. Retrieved August 6, 2019, from https:// www.bmi.bund.de/SharedDocs/downloads/EN/publikationen/2014/federal-public-service.html

Hood, C. (1995). Deprivileging the UK Civil Service in the 1980s: Dream or Reality? In J. Pierre (Ed.), Bureaucracy in the Modern State (pp. 92-113). Cheltenham: Edward Elgar.

Kuhlmann, S., \& Wollmann, H. (2019). Introduction to Comparative Public Administration. Cheltenham: Edward Elgar.

OECD. (2019). Government at a Glance-Highlights. Paris: OECD Publishing.

Reichard, C., \& Schröter, E. (2018). Education and Training in Public Administration/Management in Europe. In E. Ongaro \& S. van Thiel (Eds.), The Palgrave Handbook of Public Administration and Management in Europe (pp. 41-60). Houndmills-New York: Palgrave Macmillan. 
Schröter, E. (2004). The Politicization of the German Civil Service: A ThreeDimensional Portrait of the Ministerial Bureaucracy. In B. G. Peters \& J. Pierre (Eds.), Politicization of the Civil Service in Comparative Perspective (pp. 55-80). London, New York: Routledge.

Van der Meer, F., Steen, T., \& Wille, A. (2015). Civil Service Systems in Western Europe: A comparative analysis. In F. Van der Meer, J. Raadschelders, \& T. Toonen (Eds.), Comparative Civil Service Systems in the 21st Century (pp. 38-56). Houndmills-New York: Palgrave Macmillan.

Open Access This chapter is licensed under the terms of the Creative Commons Attribution 4.0 International License (http://creativecommons.org/licenses/ by $/ 4.0 /$ ), which permits use, sharing, adaptation, distribution and reproduction in any medium or format, as long as you give appropriate credit to the original author(s) and the source, provide a link to the Creative Commons licence and indicate if changes were made.

The images or other third party material in this chapter are included in the chapter's Creative Commons licence, unless indicated otherwise in a credit line to the material. If material is not included in the chapter's Creative Commons licence and your intended use is not permitted by statutory regulation or exceeds the permitted use, you will need to obtain permission directly from the copyright holder.

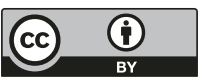

